\title{
ANALISIS TINGKAT KEKUMUHAN DAN POLA PENANGANANNYA PADA LOKASI PERMUKIMAN (Studi Kasus: Kelurahan Keputih, Surabaya)
}

\author{
Elpidia Agatha Crysta ${ }^{1}$, Yanto Budisusanto ${ }^{2}$ \\ 1,2Departemen Teknik Geomatika FTSP-ITS, Kampus ITS Sukolilo, Surabaya, 60111 \\ e-mail: ${ }^{1}$ elpidiaagatha@gmail.com
}

\begin{abstract}
Abstrak
Kota Surabaya sebagai ibukota dari Provinsi Jawa Timur merupakan kota metropolitan terbesar kedua di Indonesia. Pertumbuhan penduduk yang terus meningkat dan tingginya tingkat migrasi mengakibatkan sebagian besar masyarakat menempati lokasi tempat tinggal yang tidak sesuai standar sehingga menimbulkan permasalahan permukiman kumuh. Kelurahan Keputih sebagai salah satu kawasan dengan perkembangan kegiatan bisnis, pendidikan dan perdagangan yang pesat, terindikasi terdapat kawasan kumuh. Oleh karena itu, dilakukan pemetaan kawasan kumuh yang kemudian diklasifikasikan berdasarkan empat tingkat kekumuhan yakni, bukan kawasan kumuh, kawasan kumuh ringan, kawasan kumuh sedang dan kawasan kumuh berat. Dari klasifikasi tersebut ditambah dengan variabel legalitas lahan dapat direncanakan pola penanganan sesuai penetapan lokasi kawasan kumuh. Metode skoring digunakan penelitian ini dalam melakukan identifikasi kawasan permukiman kumuh dengan menggunakan tujuh indikator kekumuhan dari Direktorat Pengembangan Kawasan Pemukiman, 2016 yaitu: kondisi bangunan, kondisi jalan lingkungan, kondisi drainase lingkungan, kondisi penyediaan air minum, kondisi pengelolaan air limbah, kondisi pengelolaan persampahan dan kondisi proteksi kebakaran. Hasil penelitian menunjukkan di Kelurahan Keputih hanya menghasilkan dua klasifikasi tingkat kekumuhan, 14 RT termasuk dalam bukan kawasan kumuh dengan luas total wilayah permukiman 39,839 Ha dan 10 RT termasuk dalam kawasan kumuh ringan dengan luas total wilayah permukiman 21,137 Ha. Sedangkan dari rencana pola penanganan didapatkan, 2 wilayah RT perlu pemugaran, 6 wilayah RT dilakukan permukiman kembali dan 2 wilayah RT perlu dilakukan pemugaran dan permukiman kembali.
\end{abstract}

Kata Kunci : kawasan kumuh, kekumuhan, permukiman, skoring

\section{PENDAHULUAN}

Kawasan bebas kumuh serta layak huni masih menjadi impian bagi banyak penduduk di Indonesia. Sehingga melalui RPJMN III 2015-2019 Pemerintah Indonesia telah menetapkan target yang dinamai dengan "Gerakan 100-0-100", dengan mengurangi kawasan kumuh hingga $0 \%$. Kota Surabaya sebagai kota metropolitan yang pertumbuhan penduduknya selalu naik memiliki masalah seperti tumbuhnya kawasan kumuh sepanjang bantaran sungai dan di sepanjang rel kereta api dan atau lokasi tanah negara yang tidak terawat dengan baik. Letak persebaran permukiman kumuh ini berada hampir merata diseluruh kawasan Kota Surabaya.

Kelurahan Keputih sebagai studi penelitian karena lokasi tersebut memiliki potensi terindikasi terdapat kawasan kumuh, berdasarkan identifikasi yang dilakukan oleh tim penyusun RTRW Kota Surabaya pada tahun 2004 yang diterbitkan dalam RTRW Tahun 2005 (lihat Gambar 1). Sedangkan menurut Badan Pengendalian Lingkungan Hidup
Kota Surabaya Tahun 2008, terdapat dua titik untuk sebaran lokasi kawasan kumuh tepatnya di sekitar daerah Keputih Timur dan Keputih Tegal. Hal ini sebagian besar disebabkan oleh kondisi permukiman yang semakin padat akibat jangkauan pelayanan sarana dan prasarana perkotaan, pembangunan potensi lahan yang pesat dan kegiatan.

Dalam menentukan identifikasi kawasan permukiman kumuh dilakukan dengan menentukan prioritas kriteria-kriteria yang berpengaruh terhadap kekumuhan menggunakan tujuh indikator pemukiman kumuh. Identifikasi kekumuhan dilakukan berdasarkan pengertian permukiman kumuh, serta standar pelayanan minimal yang dipersyaratkan secara nasional berdasarkan beberapa indikator yaitu: bersadarkan kementrian pekerjaan umum dan perumahan rakyat yaitu (Direktorat Pengembangan Kawasan Pemukiman, 2016) Kondisi Bangunan Gedung, Kondisi Lingkungan Jalan, Kondisi Penyediaan Air Minum, Kondisi Drainase Lingkungan, Kondisi Pengelolaan Air 
Limbah, Kondisi Pengelolaan Persampahan dan Kondisi Proteksi Kebakaran beserta Legalitas Lahan di Kelurahan Keputih. Untuk analisis penelitian akan menghasilkan klasifikasi tingkat kekumuhan dan perencanaan pola penanganan di Kelurahan Keputih, Kota Surabaya.

\section{METODE}

Lokasi penelitian ini mengambil studi kasus di Kelurahan Keputih yang berada di Kota Surabaya yang memiliki letak geografis $112^{\circ} 46^{\prime} 53^{\prime \prime}-$ $112^{\circ} 50^{\prime} 48^{\prime \prime}$ BT dan $7^{\circ} 16^{\prime} 14^{\prime \prime}-7^{\circ} 18^{\prime} 36^{\prime \prime}$ LS. Dengan batas wilayah utara Kelurahan Gebang Putih dan Kecamatan Mulyorejo, barat dengan Kelurahan Klampis Ngasem, selatan dengan Kelurahan Medokan Semampir, Kelurahan Semolowaru dan Kecamatan Rungkut serta batas timur dengan Selat Madura.

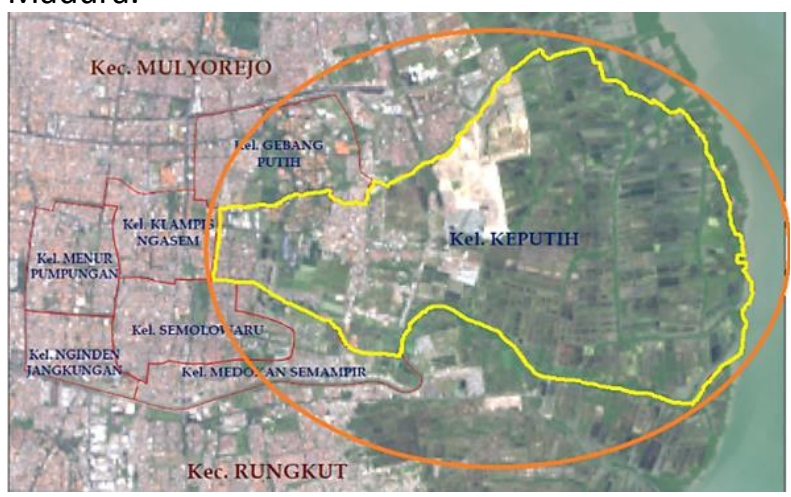

Gambar 1. Lokasi Penelitian

Peta kerja yang digunakan yaitu overlay citra resolusi tinggi Pleiades $1 A$ yang telah terektifikasi, batas administrasi, batas RT yang diperoleh secara kartometrik partisipatif dari masyarakat, jaringan jalan, dan jaringan sungai. Untuk mendukung analisa dan perolehan data indikator kekumuhan dilakukan survei dan wawancara dan mengisi form kuisioner mengenai program peningkatan kualitas permukiman dan kuisioner stakeholder mengenai lingkungan permukiman kumuh. Identifikasi Tingkat Kekumuhan dilakukan dengan memberikan skor pada kriteria-kriteria berdasarkan skala penilaian yang mempengaruhi kawasan permukiman kumuh dari setiap indikator. Kemudian dilakukan analisis hingga menghasilkan klasifikasi tingkat kawasan kumuh tiap RT. Berikut ini merupakan kriteria-kriteria pada setiap indikator kekumuhan yang dapat dilihat pada Tabel 1:
Tabel 1. Kriteria-Kriteria Indikator Kekumuhan

\begin{tabular}{|c|c|c|}
\hline No & Parameter & Sub Kriteria \\
\hline \multirow{3}{*}{1.} & \multirow{3}{*}{$\begin{array}{l}\text { Kondisi } \\
\text { Bangunan } \\
\text { Gedung }\end{array}$} & Ketidakteraturan Bangunan \\
\hline & & Tingkat Kepadatan Bangunan \\
\hline & & $\begin{array}{l}\text { Ketidaksesuaian Dengan Persyaratan } \\
\text { Teknis Bangunan }\end{array}$ \\
\hline \multirow{2}{*}{2.} & \multirow{2}{*}{$\begin{array}{l}\text { Kondisi } \\
\text { Jalan } \\
\text { Lingkungan } \\
\end{array}$} & Cakupan Pelayanan Jalan Lingkungan \\
\hline & & Kualitas Permukaan Jalan Lingkungan \\
\hline \multirow{2}{*}{3.} & \multirow{2}{*}{$\begin{array}{l}\text { Kondisi } \\
\text { Penyediaan } \\
\text { Air Minum }\end{array}$} & $\begin{array}{l}\text { Ketidaktersediaan Akses Aman Air } \\
\text { Minum }\end{array}$ \\
\hline & & $\begin{array}{l}\text { Tidak Terpenuhinya Kebutuhan Air } \\
\text { Minum }\end{array}$ \\
\hline \multirow{5}{*}{4.} & \multirow{5}{*}{$\begin{array}{l}\text { Kondisi } \\
\text { Drainase } \\
\text { Lingkungan }\end{array}$} & $\begin{array}{l}\text { Ketidakmampuan Mengalirkan } \\
\text { Limpasan Air }\end{array}$ \\
\hline & & Ketidaktersediaan Drainase \\
\hline & & $\begin{array}{l}\text { Ketidakterhubungan Dengan Sistem } \\
\text { Drainase }\end{array}$ \\
\hline & & Tidak Terpeliharanya Drainase \\
\hline & & Kualitas Konstruksi Drainase \\
\hline \multirow{2}{*}{5.} & \multirow{2}{*}{$\begin{array}{l}\text { Kondisi } \\
\text { Pengelolaan } \\
\text { Air Limbah }\end{array}$} & $\begin{array}{l}\text { Sistem Pengelolaan Air Limbah Tidak } \\
\text { Sesuai Standar Teknis }\end{array}$ \\
\hline & & $\begin{array}{l}\text { Prasarana Dan Sarana Pengelolaan Air } \\
\text { Limbah Tidak Sesuai Standar Teknis }\end{array}$ \\
\hline \multirow{3}{*}{6.} & \multirow{3}{*}{$\begin{array}{l}\text { Kondisi } \\
\text { Pengelolaan } \\
\text { Persampahan }\end{array}$} & $\begin{array}{l}\text { Prasarana Dan Asarana Persampahan } \\
\text { Tidak Sesuai Standar Teknis }\end{array}$ \\
\hline & & $\begin{array}{l}\text { Sistem Pengelolaan Persampahan Tidak } \\
\text { Sesuai Standar Teknis }\end{array}$ \\
\hline & & $\begin{array}{l}\text { Tidak Terpeliharanya Sarana Dan } \\
\text { Prasarana }\end{array}$ \\
\hline \multirow{2}{*}{7.} & \multirow{2}{*}{$\begin{array}{l}\text { Kondisi } \\
\text { Proteksi } \\
\text { Kebakaran }\end{array}$} & $\begin{array}{l}\text { Ketidaktersediaan Prasarana Proteksi } \\
\text { Kebakaran }\end{array}$ \\
\hline & & $\begin{array}{l}\text { Ketidaktersediaan Sarana Proteksi } \\
\text { Kebakaran }\end{array}$ \\
\hline
\end{tabular}

Sumber: Direktorat Pengembangan Kawasan Pemukiman, 2016

Dari subkrietria setiap indikator pada Tabel 1, langkah selanjutnya adalah sebagai berikut:

a. Pemberian skor setiap sub kriteria, berdasarkan parameter penilaian:

-Kualitas Baik (0\%-25\%) : Skor 0

-Kualitas Cukup Baik (26\% - 50\%) : Skor 1

-Kualitas Buruk (51\% - 75\%) : : Skor 3

-Kualitas Baik 76\% - 100\%) : : Skor 5

b. Perhitungan total penilaian setiap indikator didekati dengan menggunakan rumus sebagai berikut:

$$
\mathrm{Si}=\frac{\sum B i}{\sum P}
$$

Keterangan :

$\mathrm{Si}=$ Total Skor pada Setiap Indikator, $\mathrm{Bi}=$ Skor

Sub Kriteria, $\mathrm{P}=$ Jumlah Sub Kriteria

c. Klasifikasi Tingkat Kekumuhan

Berikut merupakan rentang nilai tingkat klasifikasi yang didapatkan untuk setiap kelas yakni:

-Bukan Kawasan Kumuh : $0-8,75$

-Kawasan Kumuh Ringan : 8,76-17,50 
-Kawasan Kumuh Sedang : 17,51-26,25

-Kawasan Kumuh Berat : :26,26

Penentuan penangananan dilakukan dengan memasukkan data status legalitas lahan digunakan sebagai variabel pokok dalam perencanaan pola penanganan kawasan kumuh dan tipologi kawasan kumuh. Tipologi kawasan kumuh akan memberikan kategori permukiman tersebut, dimana terdiri dari permukiman kumuh di atas air, di tepi air, di dataran rendah, di perbukitan atau di daerah rawan bencana. Status lahan memiliki hak legal yakni, dibuktikan dengan surat kepemilikan lahan atau kesesuaian dengan Rencana Tata Ruang. Pola penanganan kawasan kumuh memiliki tiga kategori yakni, peremajaan, pemugaran dan permukiman kembali. Dan berikut ini ketentuan dalam pemilihan perencanaan penanganan kawasan kumuh:

- Klasifikasi kekumuhan berat dengan status lahan legal, pola penanganan adalah peremajaan

- Klasifikasi kekumuhan berat dengan status lahan ilegal, pola penanganan adalah pemukiman kembali

- Klasifikasi kekumuhan sedang dengan status lahan legal, pola penanganan adalah peremajaan

- Klasifikasi kekumuhan sedang dengan status lahan ilegal, pola penanganan adalah pemukiman kembali

- Klasifikasi kekumuhan ringan dengan status lahan legal, pola penanganan adalah pemugaran

- Klasifikasi kekumuhan ringan dengan status lahan ilegal, pola penanganan adalah pemukiman kembali.

\section{HASIL DAN PEMBAHASAN}

Hasil skoring dari setiap indikator berdasarkan hasil penilaian dari sub kriteria untuk mengetahui tingkat kualitas yang digunakan analisis untuk penanganan permukiman kumuh dapat dilihat pada Tabel 2. Dari hasil Tabel 2 dapat dilihat untuk tingkat kualitas setiap indikator kekumuhan di setiap lokasi, semakin besar hasil skor yang didapatkan maka semakin buruk kualitas yang ada dan sebaliknya semakin kecil skor yang didapatkan maka kualitas semakin baik. Dari hasil skor tersebut juga dapat diketahui permasalahan penyebab kekumuhan dari setiap lokasi.
Tabel 2. Skoring Kriteria Indikator Kekumuhan

\begin{tabular}{|c|c|c|c|c|c|c|c|c|}
\hline \multirow{2}{*}{ RW } & \multirow{2}{*}{ RT } & \multicolumn{7}{|c|}{ HASIL SKOR } \\
\cline { 3 - 9 } & & $I 1$ & $I 2$ & $I 3$ & $I 4$ & 15 & 16 & 17 \\
\hline 01 & 01 & 0,3 & 0,5 & 0 & 0,2 & 0 & 0 & 5 \\
\hline 01 & 02 & 0,3 & 0 & 0 & 0 & 0 & 0 & 5 \\
\hline 01 & 03 & 0,3 & 0 & 0 & 0 & 0 & 2 & 5 \\
\hline 01 & 04 & 0 & 0 & 0 & 0 & 0 & 1 & 5 \\
\hline 01 & 05 & 1 & 1,5 & 0 & 0,4 & 0 & 0 & 5 \\
\hline 02 & 01 & 2 & 1,5 & 2,5 & 2,6 & 1,5 & 2 & 5 \\
\hline 02 & 02 & 0 & 0 & 0 & 0,6 & 0 & 0 & 5 \\
\hline 02 & 03 & 1 & 0 & 0 & 0 & 0 & 0 & 5 \\
\hline 02 & 04 & 0 & 0,5 & 2,5 & 0,2 & 5 & 0,7 & 5 \\
\hline 02 & 05 & 0 & 1,5 & 0 & 2,4 & 0 & 0 & 5 \\
\hline 03 & 01 & 0,3 & 0 & 0 & 0 & 0 & 1 & 5 \\
\hline 03 & 02 & 1 & 0 & 0 & 1,2 & 0 & 2 & 5 \\
\hline 03 & 03 & 1 & 0,5 & 0 & 0 & 0 & 0 & 5 \\
\hline 03 & 04 & 1 & 0 & 0 & 0 & 0 & 0 & 5 \\
\hline 03 & 05 & 0,3 & 0 & 0 & 0 & 0 & 0 & 5 \\
\hline 03 & 06 & 0,3 & 0 & 0 & 0 & 0 & 0 & 5 \\
\hline 08 & 01 & 1 & 0,5 & 0 & 0 & 0 & 0 & 5 \\
\hline 08 & 02 & 2,7 & 0 & 0 & 0,4 & 2 & 2 & 5 \\
\hline 08 & 03 & 1,7 & 0 & 2,5 & 0 & 0 & 0 & 5 \\
\hline 08 & 04 & 2 & 2,5 & 2,5 & 0,6 & 1,5 & 1 & 5 \\
\hline 08 & 05 & 1 & 0 & 0 & 0 & 0 & 0 & 5 \\
\hline 08 & 06 & 0 & 0 & 2,5 & 1 & 1,5 & 3,3 & 5 \\
\hline 08 & 07 & 1,7 & 2 & 2,5 & 2 & 0,5 & 1,7 & 5 \\
\hline 08 & 08 & 0 & 0 & 2,5 & 0,6 & 3 & 1,7 & 5 \\
\hline
\end{tabular}

Sumber: Hasil Analisis, 2017

\section{Keterangan:}

11: Bangunan Gedung

12: Jalan Lingkungan

13: Penyediaan Air Minum

14: Drainase Lingkungan

15: Pengelolaan Air Limbah

16: Pengelolaan Persampahan

17 : Proteksi Kebakaran

Tingkat kekumuhan beserta identifikasi legalitas lahan berdasarkan hasil survei dan orientasi lapangan yang dapat dilihat pada Tabel 3. Dari hasil klasifikasi diperoleh hasil yaitu, 10 lokasi di Kelurahan Keputih teridentifikasi kawasan kumuh ringan dan 14 lokasi sisanya terindikasi bukan kawasan kumuh, dengan kondisi tipologi kawasan kumuh, yaitu:

1. Kumuh di dataran rendah dan tepi air: RW 01 RT 02, RW 08 terdiri dari RT 03, RT 04, RT 06 dan RT 08.

2. Kumuh di tepi air: RW 02 RT 04 dan RW 08 RT 07.

3. Kumuh di daerah rawan banjir: RW 02 RT 05 .

4. Kumuh di dataran rendah: RW 03 RT 02 dan RW 08 RT 02. 
Tabel 3.Klasifikasi Kekumuhan dan Status Lahan

\begin{tabular}{|c|c|c|c|c|c|}
\hline RW & RT & $\begin{array}{c}\text { Total } \\
\text { Nilai }\end{array}$ & $\begin{array}{c}\text { Tingkat } \\
\text { Klasifikasi }\end{array}$ & $\begin{array}{c}\text { Luas } \\
(\mathrm{Ha})\end{array}$ & $\begin{array}{c}\text { Status } \\
\text { Lahan }\end{array}$ \\
\hline 01 & 01 & 6 & Bukan Kumuh & 2,157 & Legal \\
\hline 01 & 02 & 5,3 & Bukan Kumuh & 2,245 & Legal \\
\hline 01 & 03 & 7,3 & Bukan Kumuh & 2,077 & Legal \\
\hline 01 & 04 & 6 & Bukan Kumuh & 1,011 & Legal \\
\hline 01 & 05 & 7,9 & Bukan Kumuh & 3,947 & Legal \\
\hline 02 & 01 & 17,1 & Kumuh Ringan & 1,354 & Campuran \\
\hline 02 & 02 & 5,6 & Bukan Kumuh & 1,424 & Legal \\
\hline 02 & 03 & 6 & Bukan Kumuh & 6,421 & Legal \\
\hline 02 & 04 & 13,9 & Kumuh Ringan & 1,742 & Legal \\
\hline 02 & 05 & 8,9 & Kumuh Ringan & 2,119 & Legal \\
\hline 03 & 01 & 6,3 & Bukan Kumuh & 0,952 & Legal \\
\hline 03 & 02 & 9,2 & Kumuh Ringan & 3,174 & Legal \\
\hline 03 & 03 & 6,5 & Bukan Kumuh & 3,064 & Legal \\
\hline 03 & 04 & 6 & Bukan Kumuh & 2,301 & Legal \\
\hline 03 & 05 & 5,3 & Bukan Kumuh & 1,458 & Legal \\
\hline 03 & 06 & 5,3 & Bukan Kumuh & 3,546 & Legal \\
\hline 08 & 01 & 6,5 & Bukan Kumuh & 5,429 & Legal \\
\hline 08 & 02 & 12,1 & Kumuh Ringan & 7,084 & Campuran \\
\hline 08 & 03 & 9,2 & Kumuh Ringan & 0,584 & Tidak Legal \\
\hline 08 & 04 & 15,1 & Kumuh Ringan & 2,219 & Tidak Legal \\
\hline 08 & 05 & 6 & Bukan Kumuh & 3,807 & Legal \\
\hline 08 & 06 & 13,3 & Kumuh Ringan & 0,737 & Tidak Legal \\
\hline 08 & 07 & 15,4 & Kumuh Ringan & 1,110 & Tidak Legal \\
\hline 08 & 08 & 12,8 & Kumuh Ringan & 1,014 & Tidak Legal \\
\hline
\end{tabular}

Sumber: Hasil Analisis, 2017

Sedangkan hasil identifikasi status legalitas lahan didapatkan, sebanyak 17 lokasi berstatus lahan legal, sebanyak 5 lokasi berstatus lahan tidak legal dan sebanyak 2 lokasi berstatus lahan campuran. Berdasarkan informasi Tabel 3, didapatkan hasil analisis mengenai status lahan tidak legal disebabkan:

1. Status lahan tidak legal: sebanyak 5 lokasi (RT 03 RW 08, RT 04 RW 08, RT 06 RW 08, RT 07 RW 08 dan RT 08 RW 08). Status lahan tidak legal dibuktikan dengan tidak adanya surat kepemilikan setiap lahan dan ketidaksesuaian dengan RDTRK Surabaya dilihat dari arahan pengembangan yang ditunjukkan dalam pola ruang. Kelima lokasi diatas dalam arahan pengembangannya yang tertuang dalam RDTRK Surabaya adalah Kawasan Terbuka Hijau.

2. Status lahan campuran: sebanyak 2 lokasi (RT 01 RW 02, dan RT 02 RW 08). Status lahan campuran dalam hal ini terdiri dari sebagian status lahan legal dan sebagian tidak legal. RT 01 RW 02 sebagian memiliki status lahan tidak legal karena tidak adanya surat kepemilikan setiap lahan dan ketidaksesuaian dengan RDTRK Surabaya yang arah pengembangannya adalah Kawasan Perdagangan dan Pengadaan Jalan untuk daerah sampadan sungai. Dan RT 02 RW 08 sebagian memiliki status lahan tidak legal karena tidak adanya surat kepemilikan setiap lahan dan ketidaksesuaian dengan RDTRK Surabaya yang arah pengembangannya adalah Kawasan Terbuka Hijau.

Untuk perencanaan pola penanganan terhadap permukiman kumuh beserta permasalahan penyebab kekumuhan, yang dapat dilihat dari indikator yang mempunyai hasil skor tinggi yang termasuk dalam kualitas buruk hingga sangat buruk setiap kawasan di Kelurahan Keputih dapat dilihat pada Tabel 4 .

Untuk perencanaan pola penanganan setiap kawasan permukiman kumuh, yaitu:

1. Perencanaan Penanganan Pemugaran: sebanyak 3 lokasi (RT 04 RW 02, RT 05 RW 02 dan RT 02 RW 03). Pada RT 04 RW 02 harus dilakukan pemasangan untuk saluran perpiaan penyediaan air minum dan pemasangan septik tank untuk pengelolaan air limbah. Pada RT 05 RW 02 harus dilakukan pembangunan untuk saluran drainase agar terhubung dan sistem drainase lainnya. Pada RT 02 RW 03 sebaiknya dilakukan perbaikan terhadap kondisi-kondisi yang memiliki kualitas cukup baik untuk sistem, sarana maupun prasara seperti: bangunan, drainase dan pengelolaan persampahan.

2. Perencanaan Permukiman Kembali: sebanyak 5 lokasi (RT 03 RW 08, RT 04 RW 08, RT 06 RW 08, RT 07 RW 08 dan RT 08 RW 08). Kelima lokasi tersebut sebaiknya dilakukan relokasi (permukiman kembali), hal ini dikarenakan status lahan tidak legal dengan tidak adanya surat kepemilikan dan ketidaksesuaian dengan RDTRK.

3. Perencanaan Penanganan Pemugaran dan Permukiman Kembali: sebanyak 2 lokasi (RT 01 RW 02, dan RT 02 RW 08). Pada RT 01 RW 02 sebagian harus dilakukan pembangunan untuk saluran perpiaan penyediaan air minum dan saluran drainase, dan sebagian wilayah sebaiknya dilakukan relokasi (permukiman kembali), hal ini dikarenakan status lahan tidak legal. Pada RT 02 RW 08 sebagian harus dilakukan perbaikan kondisi bangunan, dan sebagian wilayah sebaiknya dilakukan relokasi (permukiman kembali), hal ini dikarenakan status lahan tidak legal. 
Tabel 4.Perencanaan Penanganan Permukiman Kumuh

\begin{tabular}{|c|c|c|c|}
\hline RW & RT & $\begin{array}{c}\text { Indikator Penyebab } \\
\text { Kekumuhan }\end{array}$ & $\begin{array}{c}\text { Perencanaan Pola } \\
\text { Penanganan }\end{array}$ \\
\hline 01 & 01 & Proteksi Kebakaran & Tidak Ada \\
\hline 01 & 02 & Proteksi Kebakaran & Tidak Ada \\
\hline 01 & 03 & Proteksi Kebakaran & Tidak Ada \\
\hline 01 & 04 & Proteksi Kebakaran & Tidak Ada \\
\hline 01 & 05 & Proteksi Kebakaran & Tidak Ada \\
\hline 02 & 01 & $\begin{array}{l}\text { Penyediaan Air Minum, } \\
\text { Drainase Lingkungan dan } \\
\text { Proteksi Kebakaran }\end{array}$ & $\begin{array}{l}\text { Pemugaran dan } \\
\text { Permukiman } \\
\text { Kembali }\end{array}$ \\
\hline 02 & 02 & Proteksi Kebakaran & Tidak Ada \\
\hline 02 & 03 & Proteksi Kebakaran & Tidak Ada \\
\hline 02 & 04 & $\begin{array}{l}\text { Penyediaan Air Minum, } \\
\text { Pengelolaan Air Limbah } \\
\text { dan Proteksi Kebakaran }\end{array}$ & Pemugaran \\
\hline 02 & 05 & $\begin{array}{c}\text { Drainase Lingkungan dan } \\
\text { Proteksi Kebakaran }\end{array}$ & Pemugaran \\
\hline 03 & 01 & Proteksi Kebakaran & Tidak Ada \\
\hline 03 & 02 & Proteksi Kebakaran & Pemugaran \\
\hline 03 & 03 & Proteksi Kebakaran & Tidak Ada \\
\hline 03 & 04 & Proteksi Kebakaran & Tidak Ada \\
\hline 03 & 05 & Proteksi Kebakaran & Tidak Ada \\
\hline 03 & 06 & Proteksi Kebakaran & Tidak Ada \\
\hline 08 & 01 & Proteksi Kebakaran & Tidak Ada \\
\hline 08 & 02 & $\begin{array}{l}\text { Kondisi Bangunan dan } \\
\text { Proteksi Kebakaran }\end{array}$ & $\begin{array}{l}\text { Pemugaran dan } \\
\text { Permukiman } \\
\text { Kembali }\end{array}$ \\
\hline 08 & 03 & $\begin{array}{l}\text { Penyediaan Air Minum } \\
\text { dan Proteksi Kebakaran }\end{array}$ & $\begin{array}{c}\text { Prermukiman } \\
\text { Kembali }\end{array}$ \\
\hline 08 & 04 & $\begin{array}{l}\text { Jalan Lingkungan, } \\
\text { Penyediaan Air Minum } \\
\text { dan Proteksi Kebakaran }\end{array}$ & $\begin{array}{l}\text { Prermukiman } \\
\text { Kembali }\end{array}$ \\
\hline 08 & 05 & Proteksi Kebakaran & Tidak Ada \\
\hline 08 & 06 & $\begin{array}{l}\text { Penyediaan Air Minum, } \\
\text { Pengelolaan Persampahan } \\
\text { dan Proteksi Kebakaran }\end{array}$ & $\begin{array}{l}\text { Prermukiman } \\
\text { Kembali }\end{array}$ \\
\hline 08 & 07 & $\begin{array}{l}\text { Penyediaan Air Minum } \\
\text { dan Proteksi Kebakaran }\end{array}$ & $\begin{array}{c}\text { Prermukiman } \\
\text { Kembali }\end{array}$ \\
\hline 08 & 08 & $\begin{array}{l}\text { Penyediaan Air Minum, } \\
\text { Pengelolaan Air Limbah } \\
\text { dan Proteksi Kebakaran }\end{array}$ & $\begin{array}{l}\text { Prermukiman } \\
\text { Kembali }\end{array}$ \\
\hline
\end{tabular}

Sumber: Hasil Analisis, 2017

Selain itu, jika dilihat dari hasil analisis berdasarkan Tabel 4 diidentifikasi bahwa seluruh lokasi di Kelurahan Keputih belum memiliki proteksi kebarakan. Hal ini disebabkan seluruh permukiman di Kelurahan Keputih masih bergantung pada pemerintah di kelurahan untuk pengamanan kebakaran.

\section{KESIMPULAN}

Berdasarkan hasil analisis tingkat kekumuhan dan pola penanganannya maka di dapatkan beberapa kesimpulan sebagai berikut:

1. klasifikasi tingkat kekumuhan dari hasil identifikasi lokasi terdapat dua tingkat kekumuhan di Kelurahan keputih yaitu, 14 RT termasuk dalam bukan kawasan kumuh dengan luas total wilayah permukiman 39,839 Ha dan 10 RT termasuk dalam kawasan kumuh ringan dengan luas total wilayah permukiman 21,137 Ha.

2. Dari hasil penetapan lokasi kawasan kumuh, maka perencanaan pola penanganan yang dihasilkan adalah sebagai berikut:

- Perencanaan Penanganan Pemugaran: RT 04 RW 02, RT 05 RW 02 dan RT 02 RW 03.

- Perencanaan Permukiman Kembali: RT 03 RW 08, RT 04 RW 08, RT 06 RW 08, RT 07 RW 08 dan RT 08 RW 08.

- Perencanaan Penanganan Pemugaran dan Permukiman Kembali: RT 01 RW 02, dan RT 02 RW 08 (dalam hal ini sebagian wilayah harus dipugar dan sebagian wilayah dilakukan relokasi atau permukiman kembali).

Saran

1. Dalam melakukan survei dan wawancara menggunakan sarana gambaran wilayah setiap lokasi dengan perbandingan gambaran permukiman dengan kualitas layak huni sebagai properti wawancara untuk lebih memudahkan narasumber dalam melihat kondisi permukiman di lokasi saat ini.

2. Melakukan lebih banyak survei dan wawancara ke beberapa stakeholder seperti: pihak Dinas Cipta Karya bagian Perumahan dan Permukiman Kumuh dan pihak Kecamatan Sukolilo untuk mendapatkan lokasi kawasan kumuh perkotaan di Kelurahan Keputih.

\section{DAFTAR PUSTAKA}

Auliannisa, D. 2009. Permukiman Kumuh di Kota Bandung. Fakultas Matematika dan IImu Pengetahuan Alam, Departemen Geografi, Universitas Indonesia.

Direktorat Pengembangan Kawasan Pemukiman. 2016. Panduan Pendampingan Penyusunan Raperda tentang Pencegahan dan Peningkatan Kualitas Perumahan Kumuh dan Permukiman Kumuh. Jakarta: Direktorat Jenderal Cipta Karya Kementerian Pekerjaan Umum dan Perumahan Rakyat.

Direktorat Pengembangan Kawasan Pemukiman. 2016. Panduan Penyusunan Rencana Pencegahan dan Peningkatan Kualitas Permukiman 
Kumuh Perkotaan (RP2KPKP). Jakarta:

Direktorat Jenderal Cipta Karya

Kementerian Pekerjaan Umum dan

Perumahan Rakyat.

Fitria, N., dan Rulli P.S., 2014. Identifikasi Karakteristik Lingkungan Permukiman Kumuh di Kelurahan Kapuk, Jakarta Barat. Jurnal Teknik POMITS. 3, 2: C240-C244.

Heryati. 2008. Identifikasi Dan Penanganan Kawasan Kumuh Kota Gorontalo.

Ilmy, H.F. 2016. Identifikasi Kawasan Permukiman Kumuh Menggunakan Metode AHP (Analytical Hierarcy Process) (Studi Kasus:
Kecamatan Klojen, Kota Malang). Jurusan Teknik Geomatika. Fakultas Teknik Sipil dan Perencanaan. Institut Teknologi Sepuluh Nopember.

Pujihastuti, I.,. 2010. Prinsip Penulisan Kuesioner Penelitian. CEFARS : Jurnal Agribisnis dan Pengembangan Wilayah. 2, 1: 43-56.

Setiadi, A. 2012. Identifikasi Lingkungan Permukiman Kumuh di Kota Bontang. Universitas Trisakti.

Sholahuddin, M., Tanpa Tahun. SIG untuk Memetakan Daerah Banjir dengan Metode Skoring dan Pembobotan (Studi Kasus Kabupaten Jepara). 110. 